\title{
ニューヨーク世界貿易センタービルの航空機衝突時の全体応答と局部損傷の評価 STRUCTURAL RESPONSE AND DAMAGES OF NEW YORK WORLD TRADE CENTER TOWERS DUE TO IMPACTS OF AIRCRAFT ATTACKS
}

\author{
福田隆介*, 福澤栄治**, 小鹿紀 英***, 森川博司**** \\ Ryusuke FUKUDA, Eiji FUKUZAWA, Norihide KOSHIKA \\ and Hiroshi MORIKAWA
}

\begin{abstract}
At the September 11,2001, terrorist attacks on WTC1 and 2, extensive structural damage, including localized collapse, occurred at the several floor levels directly impacted by the aircraft. Despite this massive localized damage, each structure remained standing for approximately one hour or one hour and a half. Although the damage of the beams and columns in outer framed tube of each tower are clarified at the published FEMA/ASCE report, the damage of the floor system and inner core columns are not estimated. The purpose of this study is to know the reason why the buildings remained standing at the impact through the several analytical studies, such as the impact analyses using the simplified model, that estimates the overall damage, and the rigorous finite element model, that estimates the local damage, and stress analyses after some structural members are lost.
\end{abstract}

Keywords : World Trade Center, Aircraft Impact Analysis, Overall Response, Local Damage, Redundancy, Gravity Load Analysis 世界貿易センタービル、航空機衝突解析、全体応答、局部損傷、咒長性、鈶直荷重解析

\section{1. はじめに}

2001 年 9 月 11 日に発生した米国同時多発テロによるニューヨーク 世界貿易センタービル（以後WTC と記す）の崩壊は、全世界に衝撃 を与えた。特に、航空機衝突後、一定時間経過後の建物の全体崩壊 はまったく予想外の現象であった。しかしながら、航空機衝突直後 に建物は崩壊せず、WTC2(南棟)では約 1 時間程度、WTC1(北棟)では 約. 1 時間 40 分程度、避難時間を確保できたことは重要な事実であり、 航空機衝突直後に WTC1，2 がなぜ崩壊しなかったのかを解明するこ とは、今後建物の圥長性と頑強性を考慮した設計を考える上で、必 要かつ有意義なことと考えられる。

そこで本研究では、WTC1、2 を対象にまず質点系モデルにより建 物全体応答を評価し、建物の保有耐力との比較を行う。次に、詳細 な有限要素モデルにより衝突階付近の各部材の損傷状況を解析的に 評価する。その結果をもとに破断した部材を除去した状態での鈶直 荷重時応力解析を実施し、衝突直後の各柱の応力状態を評価するこ とにより、すぐには崩壊に至らなかった理由及び WTC1・に比較して WTC2が短時間で崩壊に至った理由を考察する。

\section{WTC1、2 の構造概要と部材構成}

\section{1 構造計画}

WTC1、2 は鉄骨造地上 110 階建、地下 7 階建で、軒高 $417 \mathrm{~m}$ 、基 準階高 $3.676 \mathrm{~m}$ の事務所ビルである。平面形状は図 1 に示すとおり 4 隅を面取りした $63.1 \mathrm{~m} \times 63.1 \mathrm{~m}$ の正方形で、コア部は $26.5 \mathrm{~m} \times 41.8 \mathrm{~m}$ の長方形である。コア部は図 2 に示すようにWTC1 では長手方向が 東西方向を向いているが、WTC2 では長手方向が南北方向を向いて
いる。外周部は $1.016 \mathrm{~m}$ 間隔に配置されたボックス柱約 240 本と鋼板 スパンドレル梁でチューブ架構を形成して、主たる水平方向の設計 荷重である風荷重に抵抗するとともに建物重量の約 $40 \%$ の鈶直荷重 を支持する。一方、コア部は下層階では扁平なボックス形、上層階 ではH形の柱 47 本とそれらを媻ぐ H 形小梁から構成され、建物重量 の約 $60 \%$ の鈶直荷重を支持している。床スラブは鋼製デッキプレー トに軽量コンクリートを打設し、外周柱及びコア部とピン接合され た鉄骨トラス梁で支持して床全体としてのダイヤフラムを構成して いる。また, 107 階から 110 階には図1のようにブレースが設置され、 長辺方向に 6 個、短辺方向に 4 個のアウトリカーートラスを構成して いる。

以上の構造計画に対して、柱、梁の断面形状、外形や板厚の範囲 等は、公表された各種文献等の記述で明らかであるが、各階断面の 板厚や具体的な形状配置は構造設計図面が入手出来なかったため、 必ずしも明らかでない。そこで、各構造部材の断面とその配置は、 文献 1)〜文献 3)に基づき以下のように設定した。

\section{2 外周架構}

外周柱 : 鋼板 4 枚で構成された $356 \mathrm{~mm} \times 356 \mathrm{~mm}$ ボックス柱で、板厚 を6〜76mmに変化させ、下層部6首では柱3本を 1 本に絞って $813 \mathrm{~mm}$ $\times 813 \mathrm{~mm}$ のボックス柱としている。各階の板厚分布は、常時荷重に 対する平均軸方向応力度を概ね $100 \mathrm{~N} / \mathrm{mm}^{2}$ 以下に設定し、使用鋼材の 降伏強度 450 および $690 \mathrm{~N} / \mathrm{mm}^{2}$ に対して相当の余裕度を有するよう にしている。また、 3 層 1 ユニットである柱の接合はエンドプレート 部で最大耐力 $830 \mathrm{~N} / \mathrm{mm}^{2}$ 、径 $22 \mathrm{~mm}$ のボルトで、上層部 4 本、下層部 6 本で接合している。
*鹿島 ITソリューション部 工修

** 鹿島建築設計エンジニアリング本部 工博

*** 鹿島小堀研究室 工博

***** 鹿島ITソリューション部 工博
I.T. Solutions Department, Kajima Corp., M. Eng.

Architectural and Engineering Design Division, Kajima Corp., Dr. Eng.

Kobori Research Complex, Kajima Corp., Dr. Eng.

I.T. Solutions Department, Kajima Corp., Dr. Eng. 
外周梁 : 鋼板スパンドレル梁で、梁成 $1321 \mathrm{~mm}$ 、板厚 9〜36mm、使 用鋼材の降伏強度は 450 および $690 \mathrm{~N} / \mathrm{mm}^{2}$ である。接合は高力ボル トである。
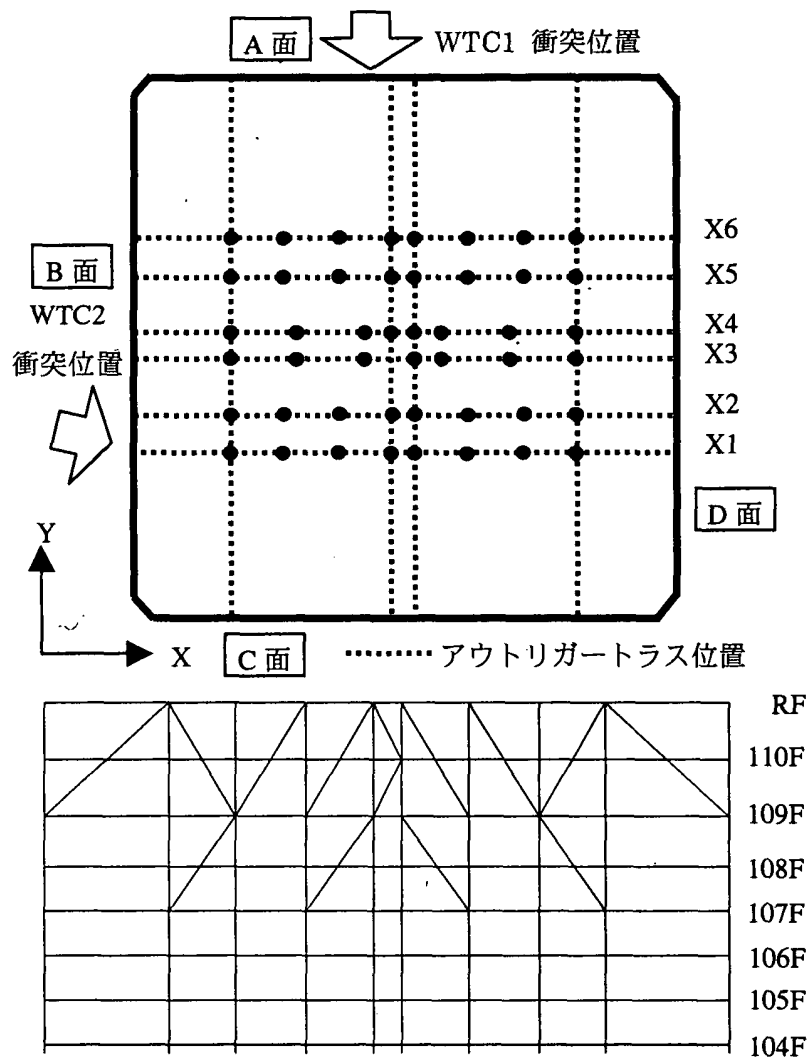

アウトリカーートラスシステム（X1 フレーム）

図1 WTC 基準階の平面形状とアウトリガートラスシステム

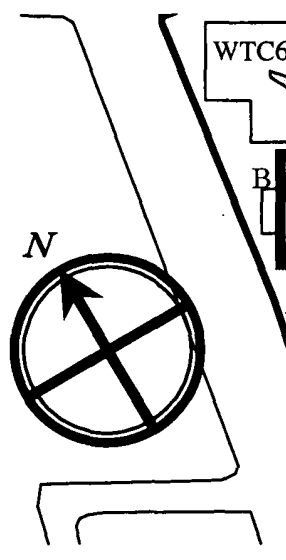

図2ＷTC 配置図と航空機衝突位置

\section{3 内部コア架構}

コア柱 : 50 階以下では $1350 \mathrm{~mm} \times 610 \mathrm{~mm}$ のボックス柱、70階以下で は $700 \mathrm{~mm} \times 550 \mathrm{~mm}$ のボックス柱、 71 階以上では H-570×454×78× 125 を最大とする超極厚 $\mathrm{H}$ 形鋼が主として採用されている。上記の 条件下で、常時荷重下の軸方向応力度が降伏強度 $248 \mathrm{~N} / \mathrm{mm}^{2}$ のほほ 2/3になるように断面の設定を行った。

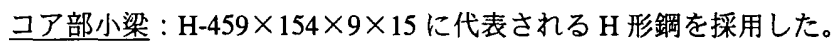
床スラブ : 鋼製デッキプレートは厚さ $1 \mathrm{~mm}$ 、溝の深さは $38 \mathrm{~mm}$ で主 トラス梁に平行に配置している。軽量コンクリートの厚さは $102 \mathrm{~mm}$ である。

\section{4 重量および設計用風荷重}

重量：建物の地上部全重量は 3630MN で、その内訳は固定荷重 $2890 \mathrm{MN}$ 、積載荷重は $740 \mathrm{MN}$ である。単位床面積当たりの平均重量 は $8.29 \mathrm{kN} / \mathrm{m}^{2}$ である。

設計用風荷重：設計用風荷重は見付面積当たり平均 $2.16 \mathrm{kN} / \mathrm{m}^{2}$ で 1 階におけるべースシア係数で約 $1.6 \%$ に相当する。

\section{WTC1 と WTC2 の航空機衝突時の全体応答評価 \\ 3.1 建物モデル}

建物モデルは WTC1、2 とも共通で、水平力抵抗機構である外周 チューブ架構の柱梁部材を曲げ・せん断・軸変形する梁要素 (一般梁 要素)で、柱梁接合部をせん断変形するパネル要素でモデル化して立 体フレームモデルを構築し、これに設計用風荷重外力を与えて静的 弾性解析を行った。生じた変形を全体曲げ変形とせん断変形に分離 して、曲げ剛性とせん断剛性を評価し、110 質点系の 1 本棒曲げせん 断モデルを作成した。各階重量は、3.30MN である。解析モデルと固 有周期を図 3 に示す。建物の減衰は強風時の実測結果 ${ }^{4)}$ に基づき、1 次と 2 次に対して $3 \%$ のレーリー減衰を仮定した。

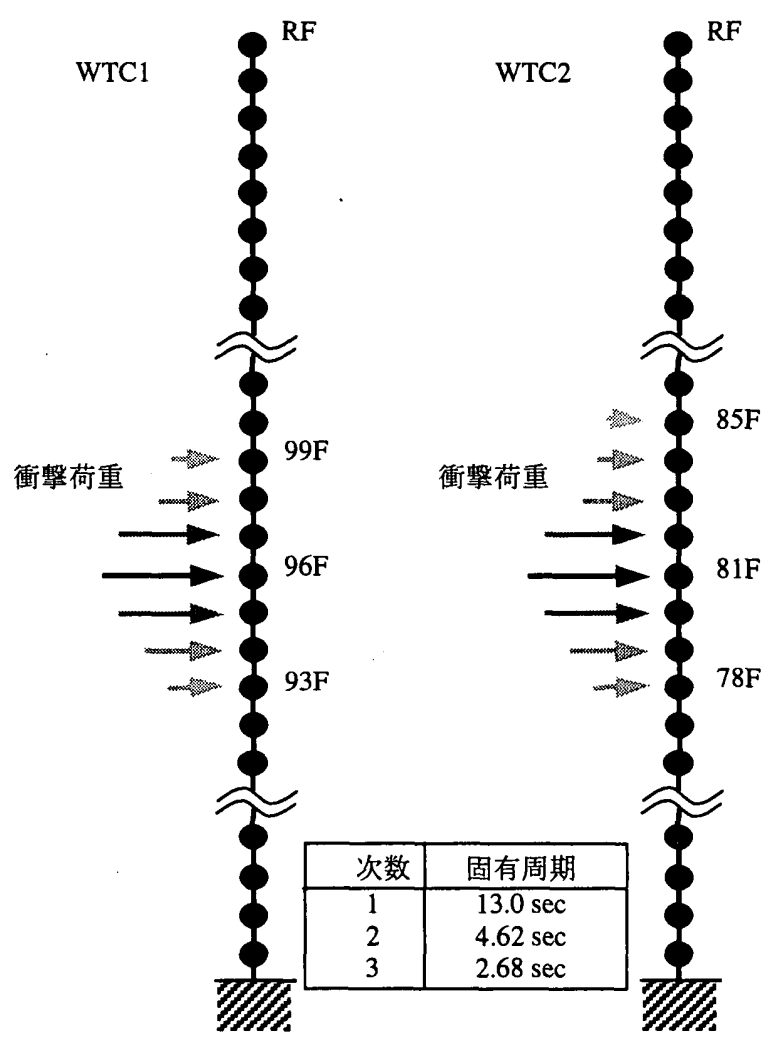

図3 WTC 110 質点系曲げせん断モデルと固有周期

\section{2 衝擊荷重}

衝撃荷重作成にあたっては、図 11 に示す航空機モデルの剛壁への 街突解析を実施し、各衝突階 (WTC1：93〜99 階、WTC2：78 階〜85 階)に対応する剛壁の反力から各質点に加えるべき衝撃荷重の時刻 歴を作成する。ただし、実際には航空機とともに建物側も損傷する ため、垌壁衝突時よりも荷重のピークは下がり、衝突時間は長くな る。そこで、WTC2 に関しては図 4 に示すビデオ映像から評価した 減速曲線を元に、剛壁衝突時の荷重の継続時間 0.25 秒を、衝突から 
機首部の貫通までの時間約 0.4 秒に継続時間を引き延ばし、力積が等 価になるように荷重を低減した。また、WTC1 に関しては、後述す る局部損傷解析の結果により、衝突から機首部が貫通するまでの時 間 0.5 秒に継続時間を引き延ばし、WTC2 と同様の処理をした。以上 のようにして作成した図 5 に示すの荷重を各衝突階に与え、時刻歴 解析を実施した。

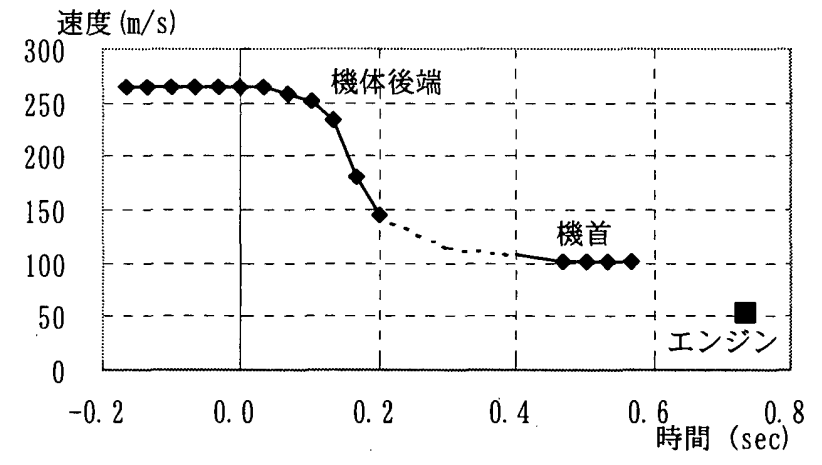

図4＼cjkstart減速曲線(ビデオ映像からの読み取り)

$\left(\times 10^{2}\right)$
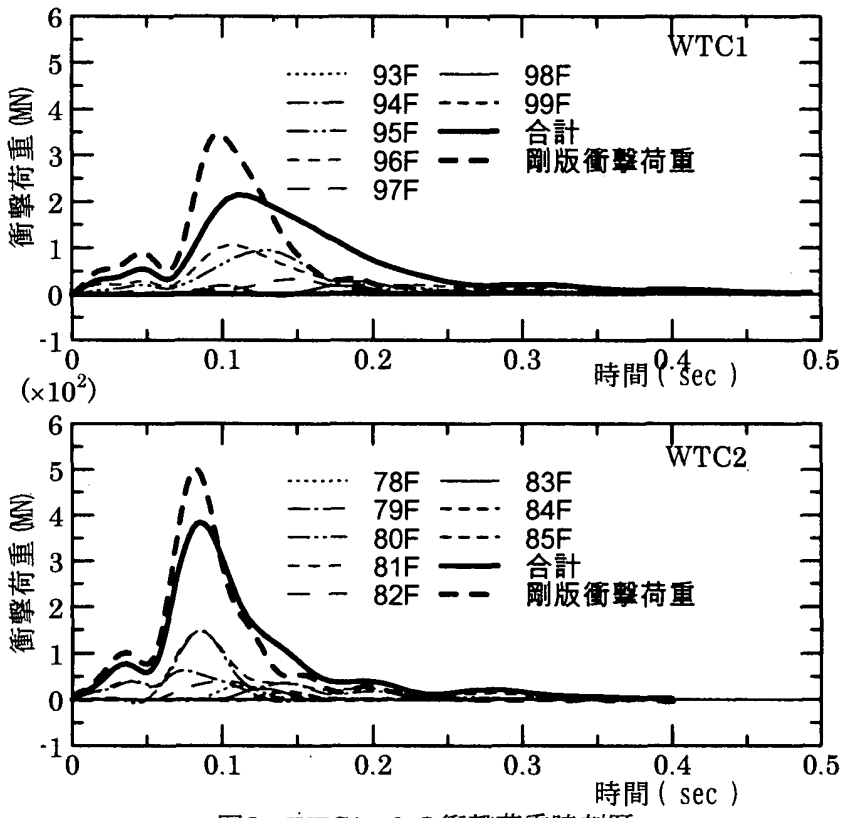

図5 WTC1、2 の衝撃荷重時刻歴

\section{3 応答結果}

図 6 9 に応答結果のうち、応答最大加速度、応答最大水平変位、 応答最大層せん断力及び応答最大転倒モーメントを示す。なお図中 には設計用風外力及びそれに対応する応答水平変位を併記している。 また、図 10 には 11 階から屋上階まで 10 階おきの応答水平変位の時 刻歴を示す。衝突階付近の応答最大加速度は WTC1 で $2 \mathrm{G}$ 弱、WTC2 で $3 \mathrm{G}$ 程度、また最大水平変位は両棟とも 80 階で $30 \mathrm{~cm}$ 強、屋上階 で $50 \mathrm{~cm}$ 程度であり、いずれの変位時刻歴波形も 1 次振動にやや高次 振動が含まれた波形になっている。また、転倒モーメントは 1 階で 設計風外力の約 $1 / 2$ 程度であるが、首せん断力は衝突階付近で設計風 荷重を大きく上回るものの、層の保有水平耐力以内にある。ここで、 層の保有水平耐力は、外周架構の荷重面内方向における柱とスパン ドレル梁において、柱頭、柱脚が断面縁で降伏強度に達する時の柱 せん断力と梁端部で曲げ縁応力度が降伏強度に達する時の柱せ九断
力のいずれか小さい方を柱の保有水平耐力として、これらを累加し て算定した。

以上より、航空機衝突時の各層の応力及び建物変形は層崩壊ある いは全体崩買に至るレベルに達していなかったことがわかる。
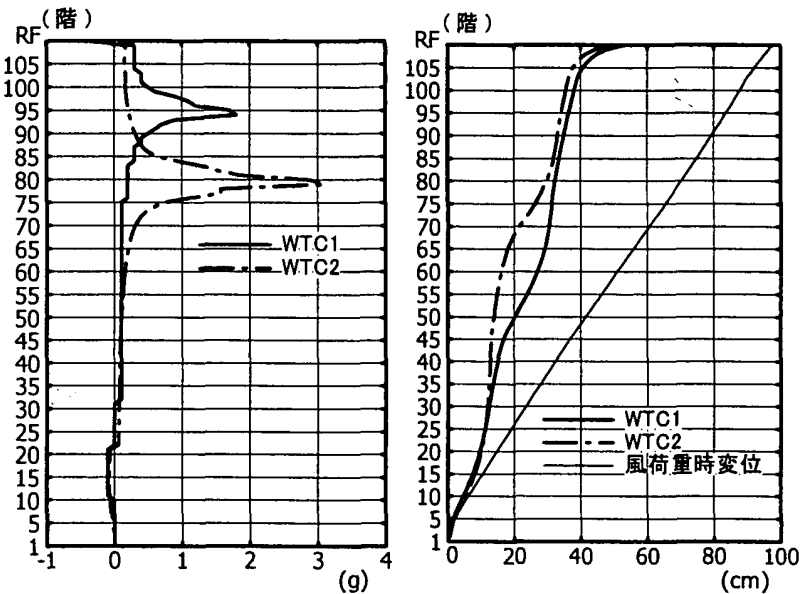

図6 応答最大加速度

図 7 応答最大水平変位
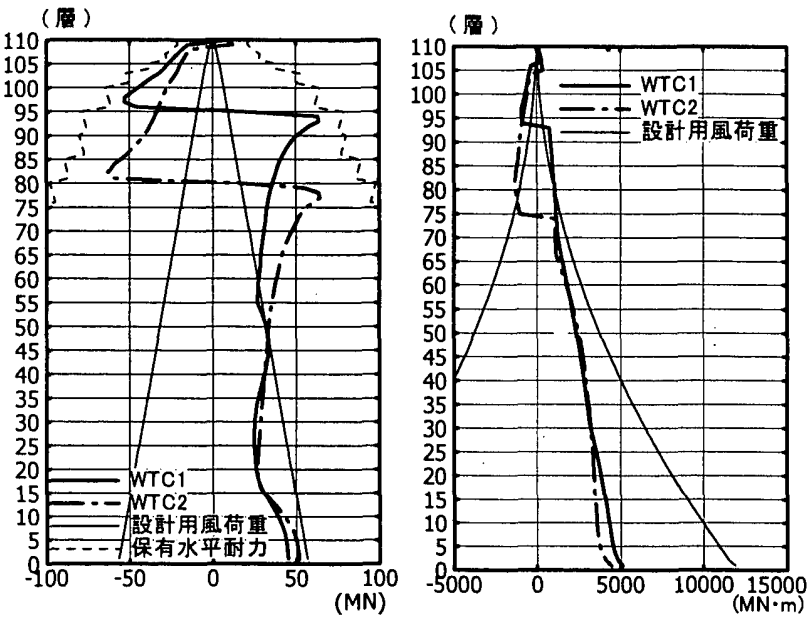

図8 応答最大層せん断力 図 9 応答最大転倒モーメント
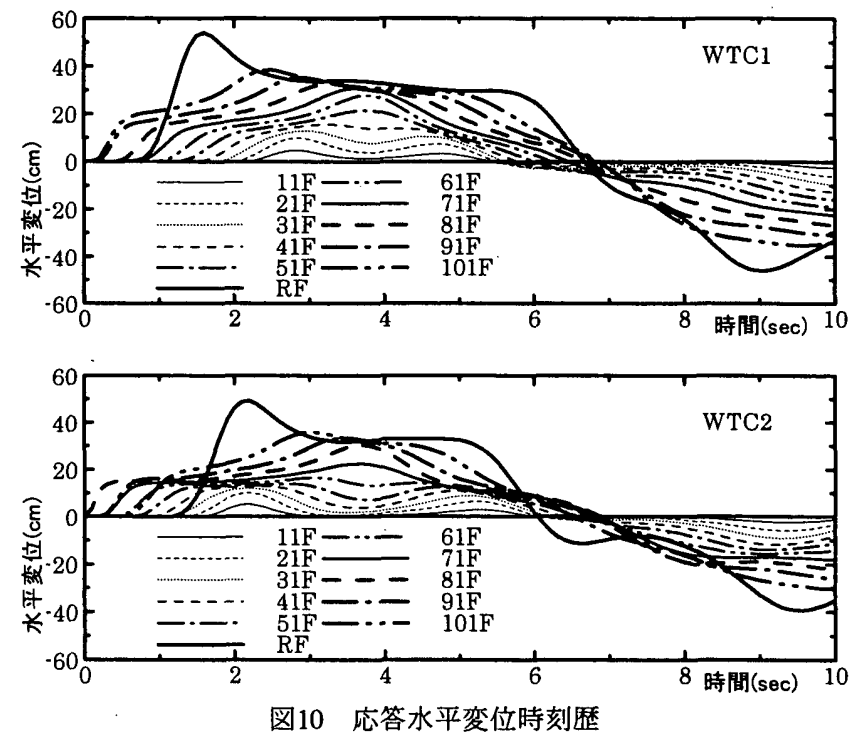

4. WTC1 とWTC2 の局部損傷評価

4.1 航空機と建物のモデル化

本章では、衝突階付近の構造部材の損傷度を評価するために、衝 


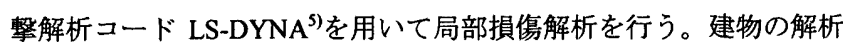
対象頒域は衝突階近傍とし、WTC1 では 92〜100 階を、また WTC2 では 77〜85 階をモデル化している。解析モデル上下端の境界条件は 水平方向にローラー支持とする。外周柱は矩形中空断面として積分 し応力評価する梁要素 ${ }^{6}$ とし、内法長さ間を 4 分割している。内部コ ア柱は、WTC1 では H 形断面として積分し応力評洒する梁要素 ${ }^{6}$ 、 WTC2 では矩形中空断面として積分し応力評価する梁要素 ${ }^{6)}$ とし、い ずれも内法長さ間を 3 分割している。一方、外周スパンドレル梁は 実際の厚みをもつシェル要素でモデル化し、床スラブは、それを構 成するコンクリート、デッキプレート、床トラス梁の上弦材を構成 するアングル材の軸方向剛性を勘案して、約 $30 \mathrm{~cm}$ の厚みを持つコン クリートのシェル要素でモデル化する。各柱には自重による初期軸 力を考慮し、柱とスパンドレル梁の破断ひずみは $10 \%$ 、床スラブの 破断ひずみは $1 \%$ とした。外周柱ユニット間をつなぐボルト 4 本はユ ニット間に锂く軸力とせん断力の複合応力で破断を表現できる接合 要素としてモデル化する。要素間の接触判定にはシェル要素は厚み を、梁要素は断面を考慮した空間的にボリュームをもつ領域を使用 する。時間刻みはクーラン条件を満たすように時々刻々変化させる。
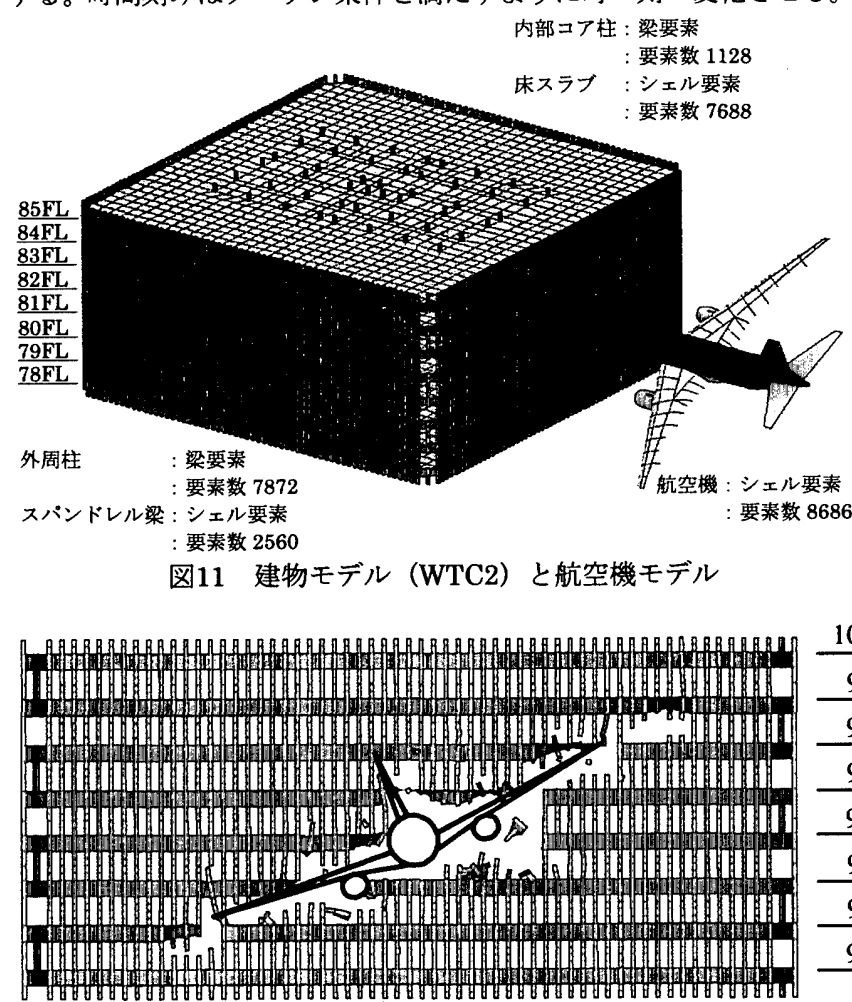

(a) 解析結果
一方航空機は、両棟共通で Boeing 767-200ER（全長 48.5m、全 幅 $47.6 \mathrm{~m}$ ) を対象とし、衝突時質量は空質量(無然料時の質量) $112.5 \mathrm{t}$ に燃料 $30 \mathrm{t}^{3}$ )を加えた総質量 $142.5 \mathrm{t}$ としている。機体は構造体である 構成部材(エンジン、胴体部リブ、主翼部リブ、隔壁、客室デッキ、 前脚、主脚、および外殼)をすべてシェル要素でモデル化し、得られ た情報の範囲内で可能な限り実物の軸方向の質量分布、強度分布が 忠実に表現できるようにモデルを作成した。作成した建物モデルと 航空機モデル(WTC2 の例)を図 11 に示す。

\section{2 解析条件}

航空機の建物への衝突位置は文献 3)の外壁の損傷状況(図 12(b)、 図 13(b))により推定される機首及びエンジンの衝突位置に対応する ように衝突させた。また衝突角度は不明であるので、文献 3)を参考 にして、WTC1 では平面的には北壁面(図 1 の A 面)に直角に、垂直 面に対しては 5 度機首を下げ、左翼を 23.5 度下げた状態で衝突させ た。一方、WTC2 では平面的には南壁面(図 1 の B 面) 11.5 度機首を 東に傾けた状態で、また垂直面に対しては 5 度機首を下げ、左翼を 35 度下げた状態で衝突させた。衝突速度は文献 3)により WTCl で $470 \mathrm{~m} . p . h .(209 \mathrm{~m} / \mathrm{s}) 、 W T C 2$ で $590 \mathrm{~m}$.p.h. $(262 \mathrm{~m} / \mathrm{s})$ とした。な拉、建物に 与える減衰は、局部的な破壊に対しては減衰の影響が小さいことを 念頭に、建物 1 次周期に対して $2 \%$ の内部粘性減衰とした。

\section{3 解析結果}

解析結果のうち、まず衝突した外壁面の損傷を図 12、図 13 に実際 の損傷 ${ }^{3}$ と比較して示す。両棟とも衝突面の破壊状況はほぼ実現象と 対応しているが、上下端の境界に近い部分の被害程度は解析がやや 大きめである。これは解析モデルの上下端の境界条件を水平ローラ 一としていることにより、応力波が境界面で全反射しているためだ と考えられる。

次に、本章の局部損傷解析結果から、破断した柱と相当塑性ひず みが 5\%を超えた柱を鉛直力が支持出来ない破壊柱と判定したが、そ の柱部材数を表 $1 、 2$ に、その平面的な位置を図 15、16 に示す。

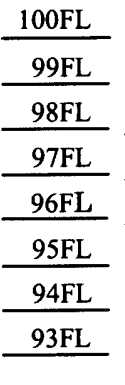

图12 WTC1 外周架構衝突面の損傷状況

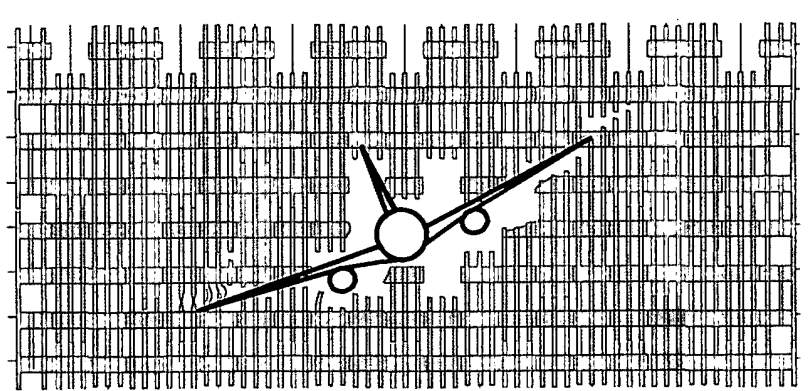

(b) 実際の損傷状況 ${ }^{3)}$

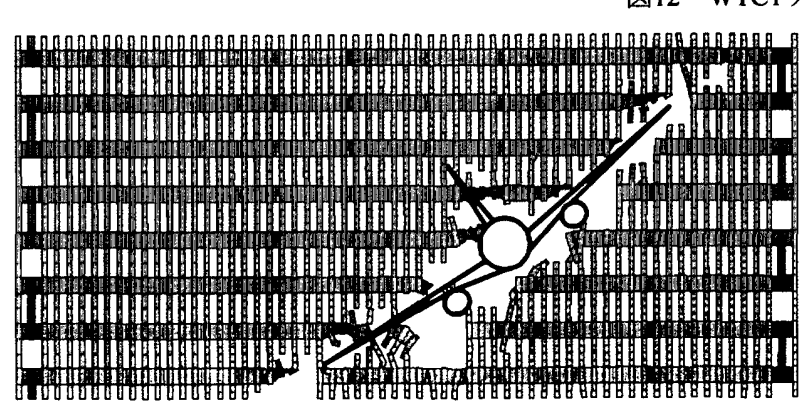

(a) 解析結果

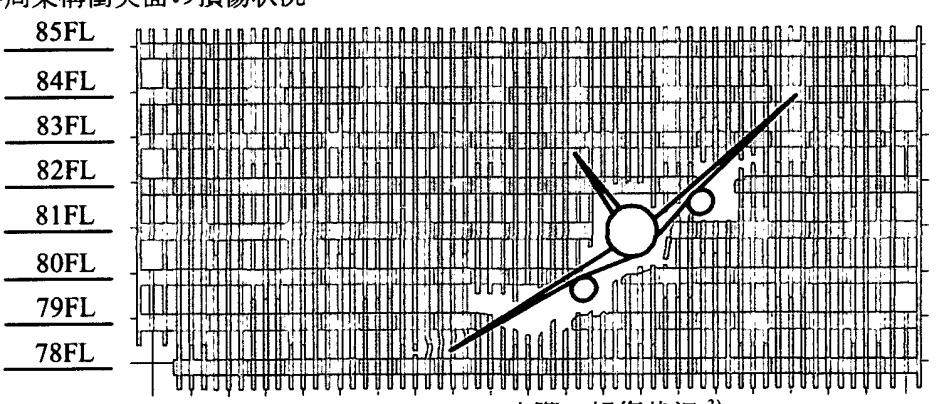

(b) 実際の損傷状況 ${ }^{3)}$

図13ＷTC2 外周架構衝突面の損傷状況 
表1 WTC1における局部損傷解析により破壊した柱部材数

\begin{tabular}{|c|c|c|c|c|c|c|}
\hline \multirow[t]{2}{*}{ 階 } & \multicolumn{4}{|c|}{ 外周柱 } & \multirow{2}{*}{ コア柱 } & \multirow[t]{2}{*}{ 計 } \\
\hline & $\mathrm{A}$ 面 & B 面 & C 面 & D 面 & & \\
\hline 99 & $\div$ & - & - & - & 1 & 1 \\
\hline 98 & 8 & - & - & - & 1 & 9 \\
\hline 97 & 11 & - & - & - & - & 11 \\
\hline 96 & 12 & - & 8 & - & 8 & 28 \\
\hline 95 & 20 & - & 10 & - & 12 & 42 \\
\hline 94 & 10 & - & 8 & - & 10 & 28 \\
\hline 93 & 3 & - & - & - & - & 3 \\
\hline 計 & 64 & - & 26 & - & 32 & 122 \\
\hline
\end{tabular}

表2 WTC2における局部損傷解析により破壊した柱部材数

\begin{tabular}{|c|c|c|c|c|c|c|}
\hline \multirow[t]{2}{*}{ 階 } & \multicolumn{4}{|c|}{ 外周柱 } & \multirow[t]{2}{*}{ コア柱 } & \multirow[t]{2}{*}{ 計 } \\
\hline & A 面 & B 面 & $C$ 面 & D 面 & & \\
\hline 84 & - & 2 & - & - & - & 2 \\
\hline 83 & - & 5 & - & 2 & - & 7 \\
\hline 82 & - & 6 & 11 & 5 & - & 22 \\
\hline 81 & - & 13 & 1 & 12 & 1 & 27 \\
\hline 80 & - & 10 & - & 8 & 6 & 24 \\
\hline 79 & - & 11 & 1 & 5 & 2 & 19 \\
\hline 78 & - & 8 & 4 & - & - & 12 \\
\hline 計 & - & 55 & 17 & 32 & 9 & 113 \\
\hline
\end{tabular}

これらより、破壊柱は、WTC1 では外周の A 面とC 面および内部コ アの中央列近くに、WTC2 では外周の B 面と C、D 面の隅に近い部 分および内部コアの C 面側に偏在する。これらをさらに詳細に見る と、WTC1 では 93〜99 階の外周柱 90 本、コア柱 26 本が破断し、コ ア柱 6 本の相当塑性ひずみが 5\%を超えている。WTC2では、78〜84 階の外周柱 104 本、コア柱 1 本が破断し、コア柱 8 本の相当塑性ひ ずみが $5 \%$ を超えている。図 14 にWTC1 96 階及び WTC2 81 階の床 スラブの損傷状況を示す。床スラブの損賃は航空機の胴体部が衝突

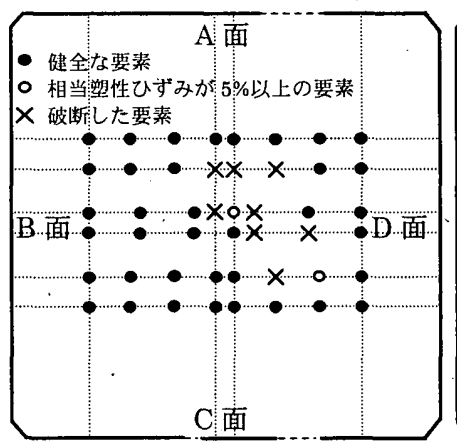

94 階

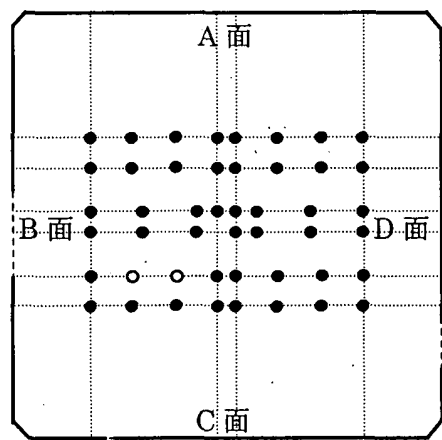

79 階

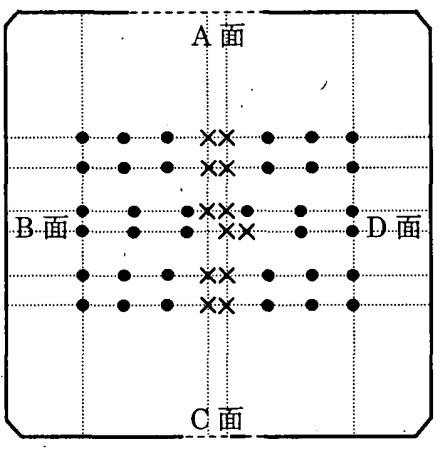

95 階

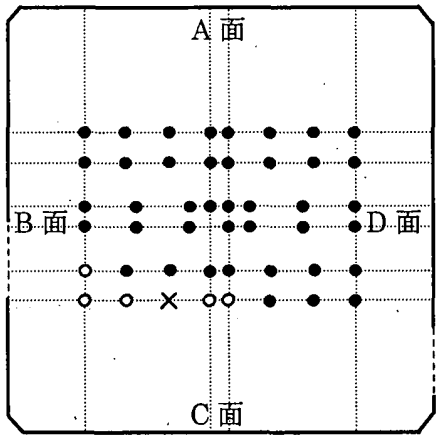

80 階

する階が一番大きかったが、外周部に近い範囲の被害にとどまり、 内部コアの内側はほとんど損傷を受けなかった。図 17 にTC1、2 それぞれに対する航空機の減速曲線を示す。WTC2 の結果には衝突 時の航空機の挙動を知る唯一のデータとして、ビデオ映像から読み 取った衝突時の航空機の減速曲線と解析結果の航空機の減速曲線を 比較している。WTC1 では、航空機の胴体部と左エンジンは 1 秒後 に、右エンジンは 0.31 秒後に静止し、建物を貫通しなかった。WTC2 では、航空機の胴体部は衝突して 0.41 秒後に機首部分の速度が $93.9 \mathrm{~m} / \mathrm{sec}$ で北側外壁面より飛び出している。右エンジンは 0.43 秒 後に北側外壁面のスパンドレル梁に衝突し急激に減速した後、 $63.5 \mathrm{~m} / \mathrm{sec}$ の残留速度で貫通している。左エンジンは衝突後 0.22 秒 後に静止し、貫通しなかった。航空機の後端及び貫通後の先端部の 減速曲線及び、右エンジンの飛び出し速度は実現象と良い一致を示 している。これより、本解析により実現象をほぼ追跡できていると 判断される。

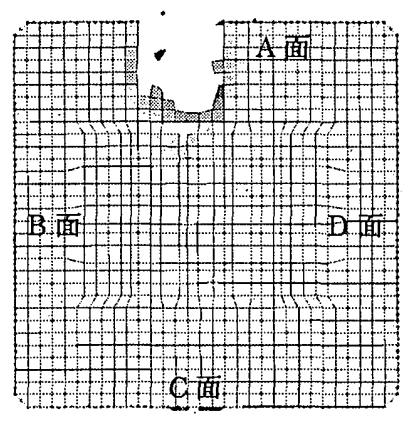

WTC1 96 階

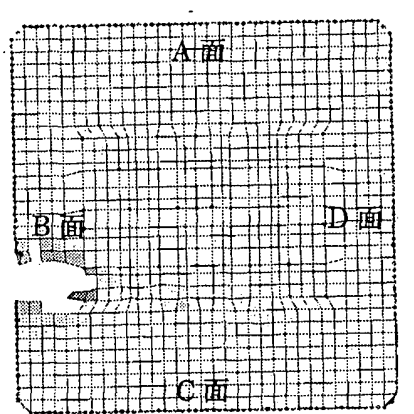

WTC2 81 階

図 14 衝突階スラブの損傷状況

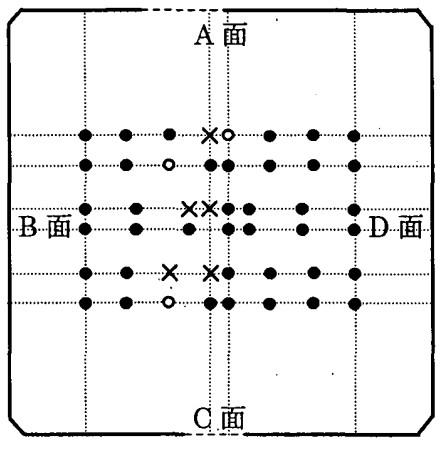

96 階

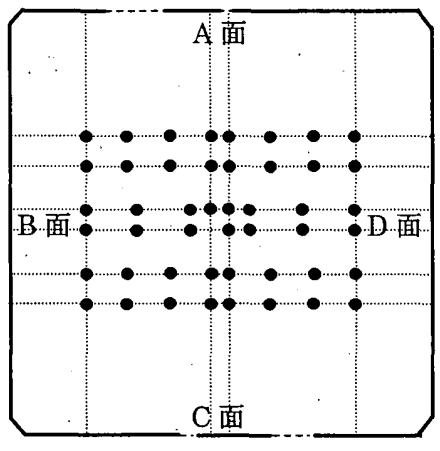

97 階 図15 WTC1 の柱の損傷状況

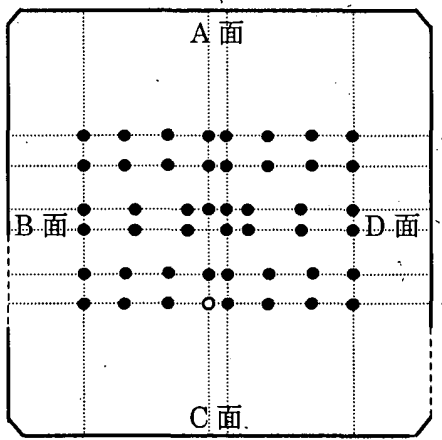

81 階

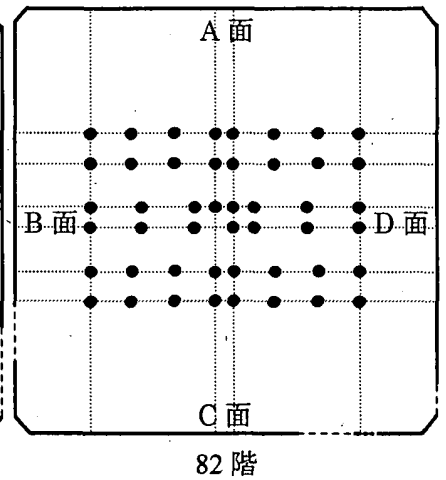

図16 WTC2 の柱の損傷状況 

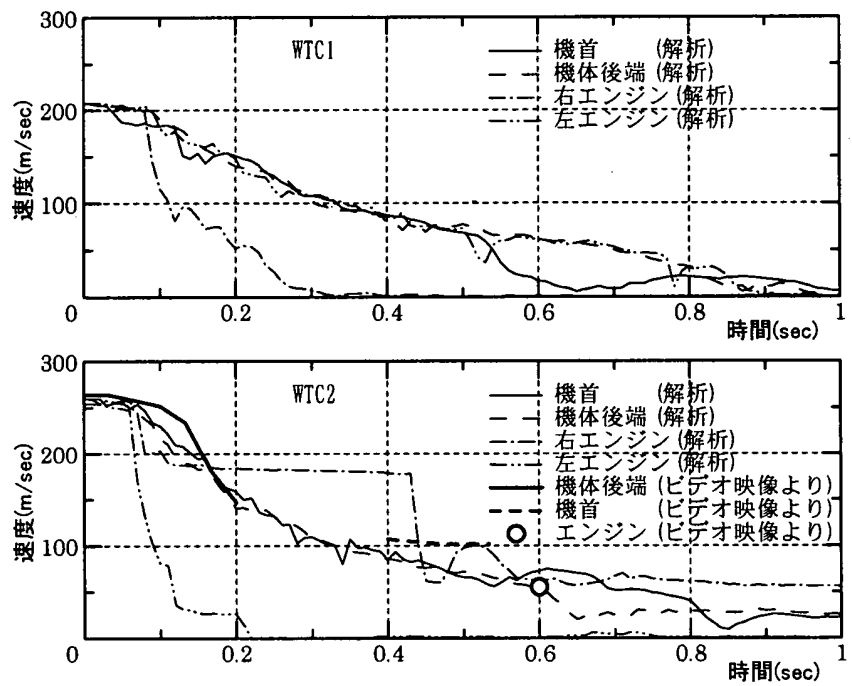

図17 衝突した航空機の減速曲線

\section{WTC1、2 の航空機衝突後の応力状態の評価と比較}

\section{1 解析モデル}

衝突前後の柱軸応力の再配分を評価するために、鈶直荷重解析用 の全体架構モデルを作成し、柱の軸方向力に対して全断面圧縮およ び引張降伏時を折点とし、第二剛性を $1 / 100$ とする二折線型の非線形 特性を考慮して、荷重増分法による非線形解析を実施する。外周于 ユーブ架構の柱·梁、及び内部コア部の柱·梁はすべて一般梁要素で モデル化し、頂部のアウトリガートラス部の斜材はトラス要素でモ デル化する。また、各階は水平方向に対して剛床仮定を設けている。 解析ケースは、WTC1、2 とも共通の衝突前の状態とそれぞれの衝突 後の状態の 3 ケースとする。衝突後のモデルは、 4 章の結果を参考に WTC1、2 において表 1 と表 2 にそれぞれ示した破壊と判定した柱. 梁部材を除去したものである。荷重は、各ケースとも解析モデルの 各節点に自重に相当する鉛直力を、 50 分割して増分載荷した。

\section{2 解析結果}

衝突前後における $80 、 90 、 95 、 110$ 階の平面的な柱軸応力度分布 を、WTC1、WTC2 それぞれについて、図 18 に示す。衝突階付近で は、外周柱の軸応力度は、衝突前が 74〜 119N/ $\mathrm{mm}^{2}$ であるのに対し、 衝突後は WTC1 では最大 $379 \mathrm{~N} / \mathrm{mm}^{2} 、$ WTC2 では最大 $285 \mathrm{~N} / \mathrm{mm}^{2}$ に 增加する。コア柱は、衝突前が 77〜 127N/ $\mathrm{mm}^{2}$ であるのに対し、衝突 後は WTC1 では最大 $201 \mathrm{~N} / \mathrm{mm}^{2} 、$ WTC2 では最大 $234 \mathrm{~N} / \mathrm{mm}^{2}$ であるが、 いずれの場合もこれらの階では残存柱は降伏には至らない。また、 破壊柱の平面的分布が WTC1 ではY 軸に対しほほ対称形であるため、 軸応力度の分布もほほ Y 軸に対し対称となるが、WTC2 では C 面側 に破壊柱が偏在するため、軸応力度の分布も $\mathrm{C}$ 面側で大きく増加す る。

図 19 に衝突前後の外周柱の軸方向力分布を示す。衝突前は 107〜 110 階のアウトリカートラスからの軸力の流れで若千の乱れはある もののほぼ均一な軸力分布を示す。これに対し、衝突後は、WTC1 および 2 とも上層からの軸力は破壊部分を迁回して流れ、破壊部分 に隣接する柱の軸応力度は応力集中により一部降伏強度を超え塑性 化するもののその近傍の柱と協同して軸力を分担することにより、 その軸ひずみは最大 $3 \%$ 以下ある。図 $20 、 21$ は、WTC1、2 それぞ れについてアウトリガートラスを含む X1〜X6 フレームの衝突後の 応力状態および塑性化状況を色別に示したもので、これより破壊し たコア柱の軸力負担分は、その直上のコア柱に引張力を発生させ、 上層のアウトリカートラス階に伝達し、ここから他のコア柱や外周 柱に流れていることが分かる。その結果、106〜110 階のコア柱は、 WTC1、 2 とも 17 本引張降伏している。この場合の最大引張ひずみ 度は、WTC1 で 0.8\%であるが WTC2 では 8.8\%に達する。

以上、衝突後の破壊による架構全体の鉛直荷重支持能力を検討す ると、WTC1、2 とも、外周架構では破壊部に隣接する柱は一部降伏 強度を超え塑性化するが、近傍の残った柱と協同して軸力を負担す ることにより、塑性化を一部の柱に留めている。また、コア部は、
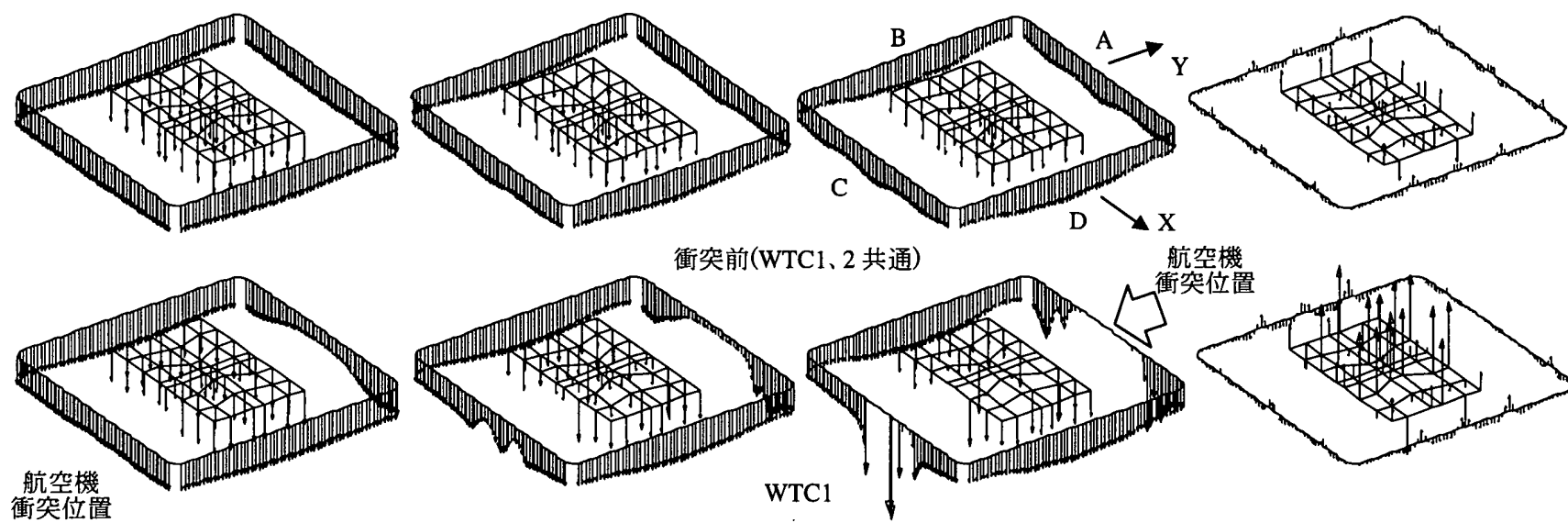

航空機

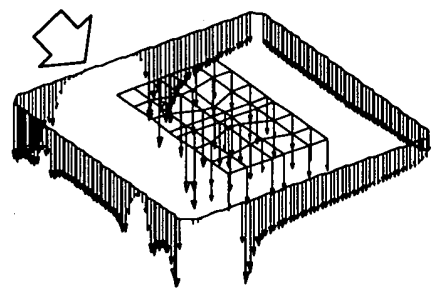

80 階

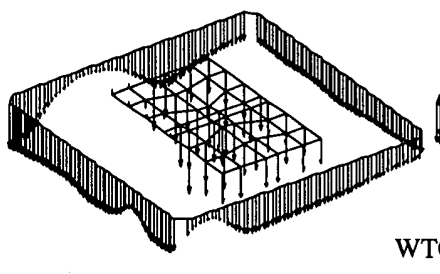

90 階

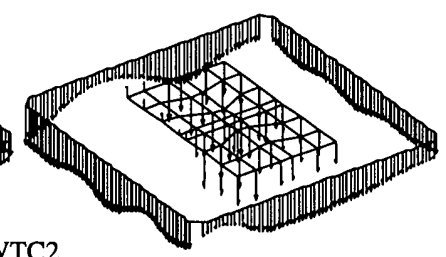

95 階
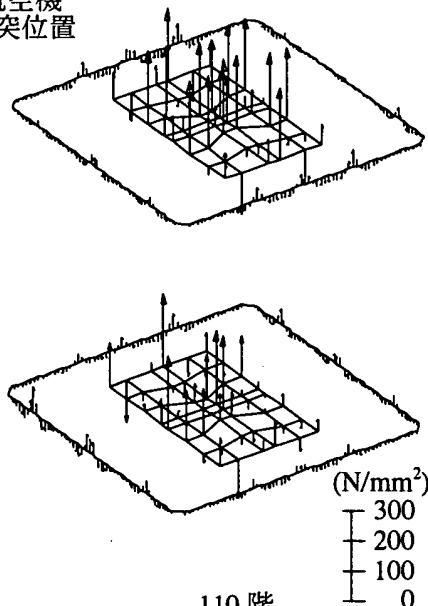

図18 衝突階の柱軸応力度の比較（上段：衝突前 中段：WTC1 下段：WTC2） 

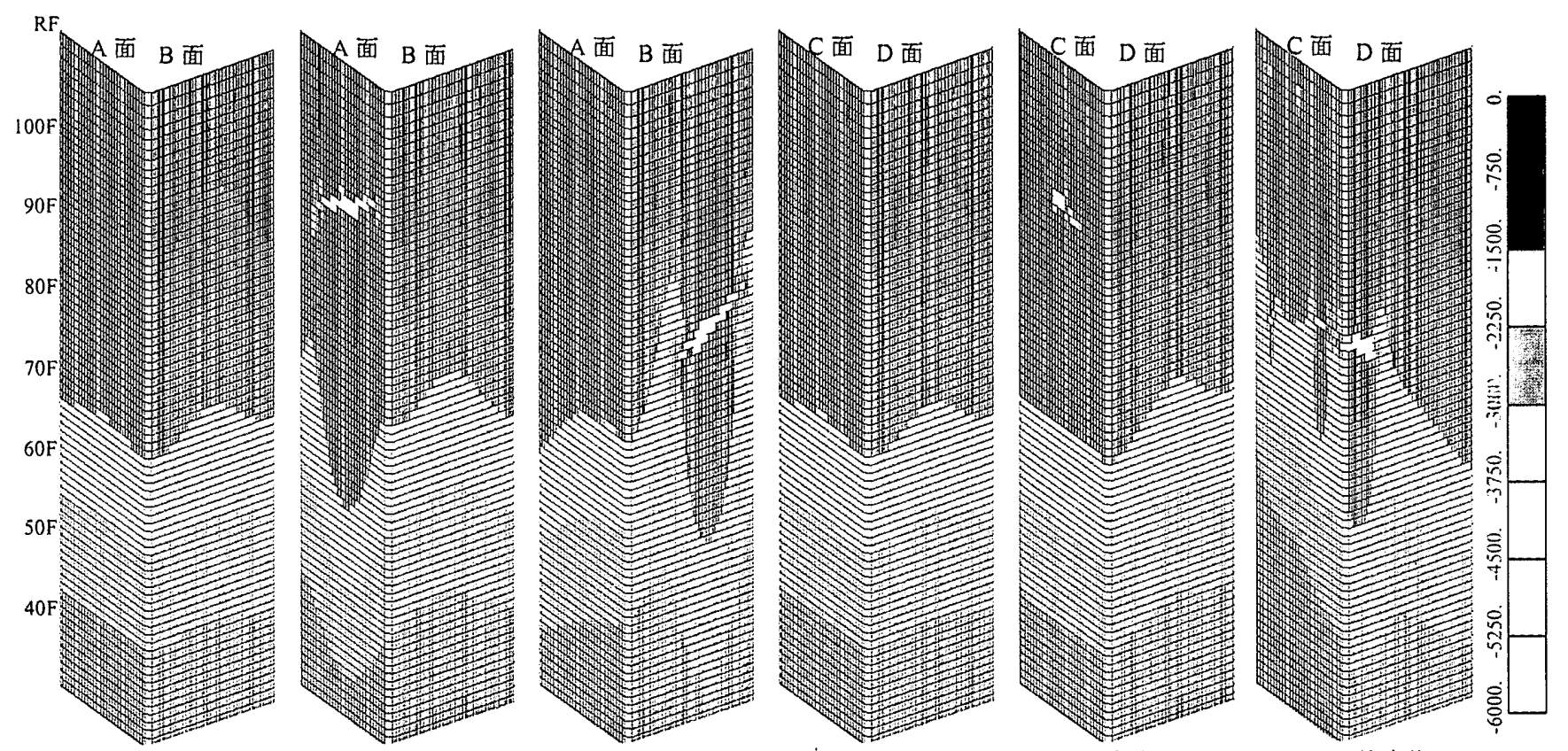

(a)衝突前 A,B 面 (b)WTC1 衝突後 A,B 面 (c)WTC2 衝突後 A,B 面 (d)衝突前 C,D 面 図19 外周柱の軸力分布
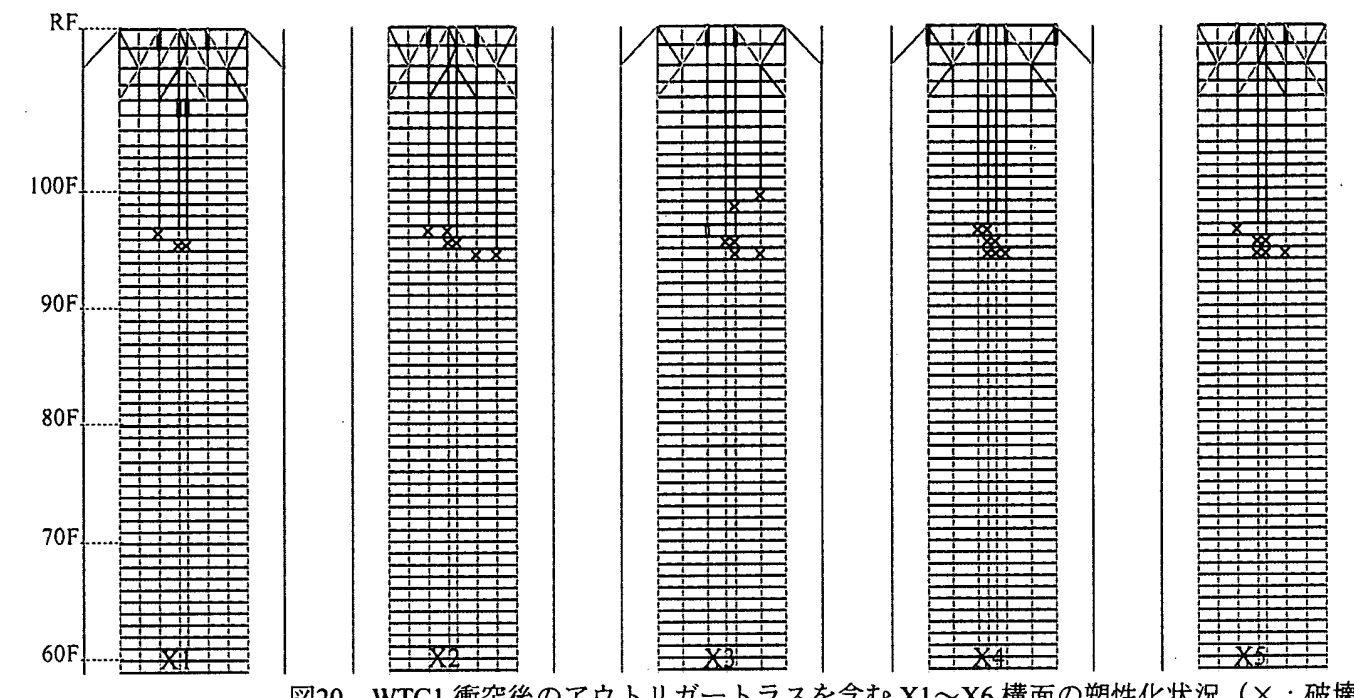

(f)WTC2 衝突後 C,D 面

(e)WTC1 衝突後 C,D 面

図20 WTC1 衝突後のアウトリガートラスを含む X1〜X6 構面の塑性化状況（X: 破壊した柱）
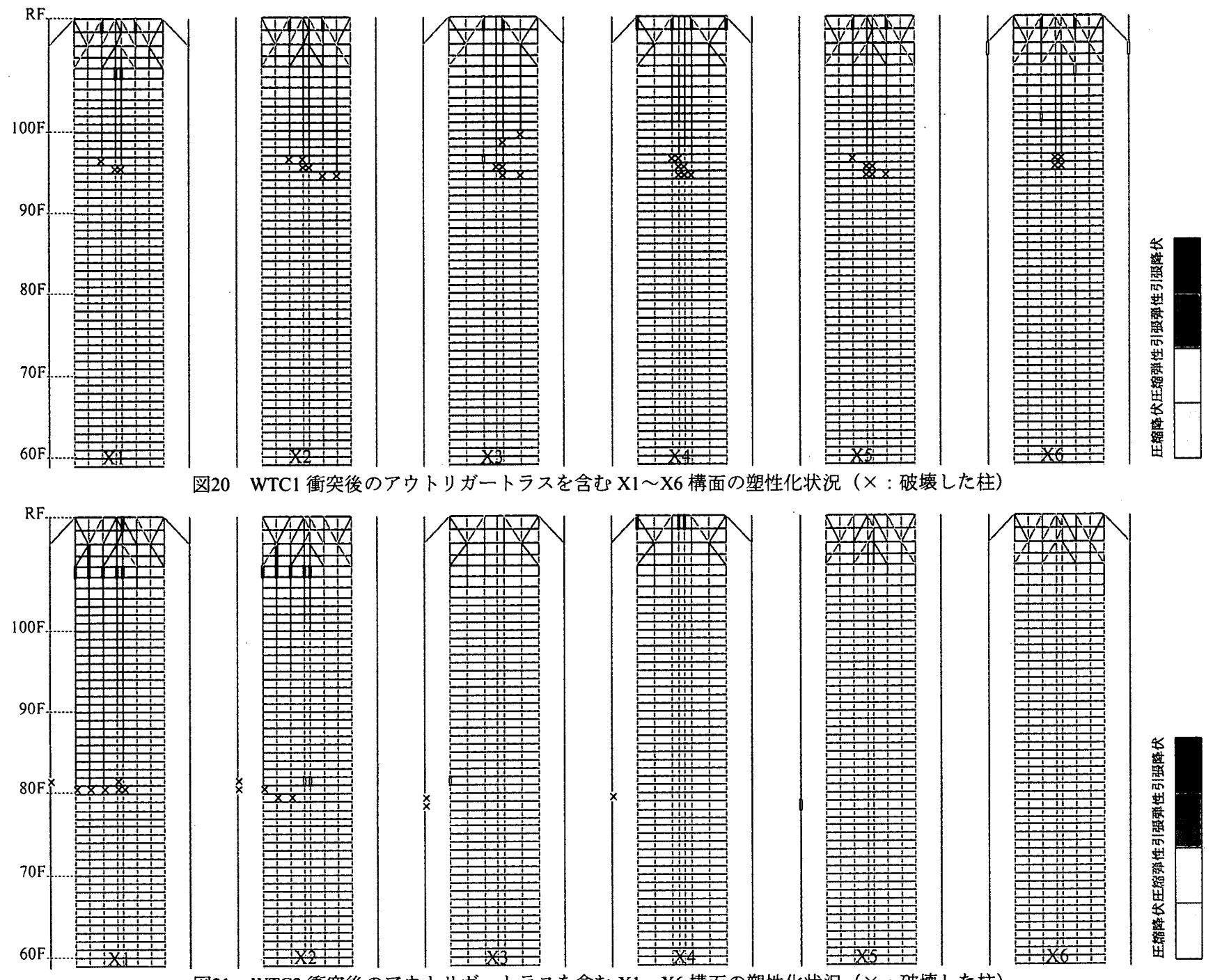

図21 WTC2 衝突後のアウトリガートラスを含む X1〜X6 構面の塑性化状況（X：破壊した柱）

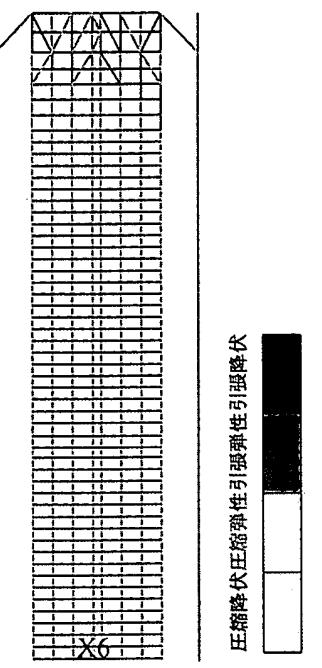


WTC1 ではコア部中央 $\mathrm{Y}$ 軸に沿った破壊柱の負担軸力分を、WTC2 では破壊した C 面側のコア柱の負担軸力分を、主にアウトリカート ラスの効果により残ったコア柱と外周架構に応力再配分されること により、架構全体としての鈶值荷重支持能力を保持していたと判断 される。図 22 に本解析による衝突後の建物上部からみた水平変位を 示す。これより、建物頂部は、WTC1 では X 軸負方向に $3.5 \mathrm{~cm} 、 Y$ 軸正方向に $5.4 \mathrm{~cm}$ 傾き、WTC2 では X 軸負方向に $17.6 \mathrm{~cm} 、 Y$ 軸負方 向に $24.0 \mathrm{~cm}$ 傾くが、これらを衝突階中心から頂部までの変形角でみ ると、WTC1 で 1/1530、WTC2 で 1/460 と過大な值にはならない。

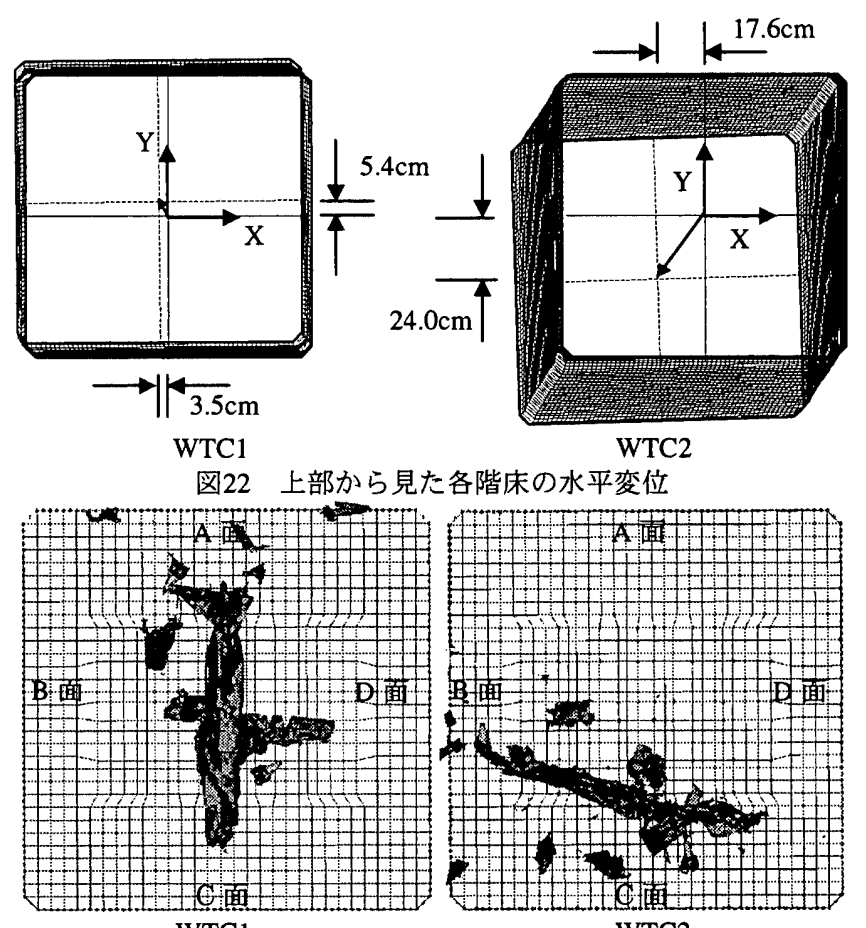

WTC1

図23 衝突航空機の飛散状況

\section{3 全体崩壊までの時間差に関する推祭}

航空機衝突後から全体崩壊までの時間は、WTC1 では 1 時間 43 分、

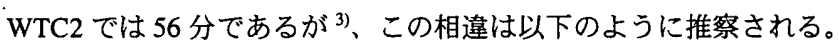

WTC1 では、95 階の A 面中央にコアの短軸方向に衝突しているた め、外周部およびコア部の柱の破壊がほぼ対称形に発生し、応力の 再配分結果による塑性化状況もほぼ対称形分布を呈した。これに対 して WTC2 では、80 階の B 面の C 面側寄りにコアの長軸方向に衝突 したため、衝突による破壊と塑性化がやや C 面寄りに偏った分布を 呈した。

一方、図 23 に示される燃料の搭載されている主翼部分の飛散状況 から、WTC1 では A 面側の短スパン部のスラブおよびコア部分を中 心に燃料が飛散したと推定されるのに対し、WTC 2 では C 面側の長 スパン部の床スラブを中心に燃料が飛散したと推定される。従って、 WTC 1 では熱容量の比較的大きいコア柱・梁部分を中心に左右対称 に残った残存柱の強度が一様に低下していき、鈶直荷重支持能力を 嘼失するまでにある程度の時間を要したと推定される。これに対し、 WTC2 では熱容量の小さい C 面側スラブを支持する鉄骨トラス梁の 端部ピン接合部が破断するとともに、軸力が集中した C 面側の外周 柱およびコア柱の一部が熱により強度低下を起こし、比較的早い段 階で鈶直荷重支持能力を失い C 面側の衝突階より上の鈶直荷重を支
持できなくなって、上階が大きく項き、全体のバランスが崩れ全体 崩壊に至ったと推定される。これはビデオ映像で観察される WTC1 はコア部が先に沈み込み、WTC2 は外周部が先に崩壊を始めたとい う現象と符合している。このように衝突後の構造部材の応力状態と 火災の領域が相まって、WTC2 の全体崩壊までの時間が WTC1 に比 ベて短かったものと推察される。

なお、この推察については上述の鈶直荷重解析に加え、熱による 強度低下を考慮したシミュレーション解析を実施して検証する予定 である。

\section{6. まとめ}

WTC1、2 を対象に航空機衝突時の損傷状況と応力状態を解析的に 評価した結果以下のことがわかった。

(1) 質点系モデルによる航空機衝突時の建物全体応答を評価した結 果、最大加速度は WTC1 で $2 \mathrm{G}$ 弱、WTC2 で $3 \mathrm{G}$ 程度、水平変位は建 物頂部で $50 \mathrm{~cm}$ 程度、また層せん断力、転倒モ一メントは上層階で一 部設計風外力を超えるものの WTC1、2 とも層の保有水平耐力以下に 納まっているため、全体崩壊には至らなかった。

(2) 詳細な有限要素モデルにより衝突階付近の構造部材の損傷状況 評価により各部材の破壊部材を把握した。その結果、WTC1、2の外 壁の損甥状況及び WTC2 の航空機の減速曲線は実現象と良い対応を 示した。また、映像等で把握できないコア部の破壊した柱は WTC1 で 32 本、WTC2 で 9 本であり、アウトリガートラスの存在等による 応力再配分の結果、架構全体として鈶直荷重支持能力が保持できて いることがわかった。また、衝突直後には衝突階より上層階は、WTC1 では約 1/1500、WTC2 では約 1/500 傾いていたことが推定される。 (3) WTC1 では、柱の破壊がほぼ対称形に発生し、応力の再配分結果 による塑性化状況もほほ対称形分布を呈した。これに対して WTC2 では、衝突による破壊と塑性化がやや $\mathrm{C}$ 面寄りに偏った分布を呈し た。また、燃料飛散による火災領域も WTC1 では A 面側の短スパン 部のスラブおよびコア部分が中心であるのに対し、WTC 2 では C 面 側の長スパン部の床スラブと柱付近が中心であった。これらの衝突 後の構造部材の応力状態と火災の領域が相まって、WTC2 の全体崩 壊までの時間が WTC1 に比べて短かったものと推察される。

\section{謝辞}

この論文の一部は、日本建筑学会 WTC 崩壊特別調査委員会 (委員長： 和田章東工大教授)での活動として実施されたものです。関倸者の皆 様に謹んで感謝の意を表します。

\section{参考文献}

1) Hart, F., Henn, W. and Sontag, H. : Muiti-Storey Buildings in Steel Second Edition, G. Bernard Godfrey MICE, FISstrctE Nichols Publishing Company, New York, pp162-164

2) 鶴田明 :アメリカの鉄骨・橋梁工作技術について,アメリカにおける最近の 超高層ビルについて(1), JSSC Vol.6 No.53 1970

3) ASCE/FEMA : World Trade Center Building Performance Study: Data Collection, Preliminary Observation, and Recommendations, 2002.5.

4) Mahmoodi, P., Robertson, L. E., et al. : Performance of Viscoelastic Dampers in World Trade Center Towers, ASCE Conference, Orland, Florida, Aug. 1987.

5) Hallquist, J. O. : LS-DYNA User's Manual, Ver 960., Livermore Software Technology Corporation, 2001

6) Hughes, T. J. R. and Liu, W. K. : Nonlinear Finite Element Analysis of Shells: Part II. Three-dimensional Shells, Computer Methods in Applied Mechanics and Engineering, pp.331-362, 1981 